
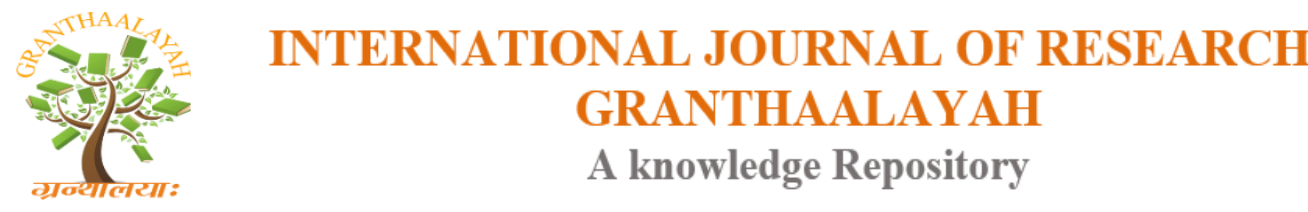

Management

\title{
SIGNIFICANCE ROLE OF TVET FOR DEVELOPING COUNTRY: STUDY ON BANGLADESH PERSPECTIVE
}

\author{
Azmat Ullah *1, Farnaz Parveen ${ }^{2}$ \\ ${ }^{1}$ Lecturer, Department of Business Administration, Port City International University, \\ Chittagong, Bangladesh \\ ${ }^{2}$ Lecturer, Department of Management Studies, Jagannath University, Dhaka, Bangladesh
}

\begin{abstract}
This paper emphasis on the role of Technical Vocational Education and Training (TVET) in development of our traditional education system into technical vocational education and training aspects in Bangladesh. The analysis in this paper reveals the limitations and opportunities of TVET in Bangladesh and provides recommendations for further enhancement of this concept application. The research has also addressed the need for an organized review of TVET in Bangladesh and its implications.
\end{abstract}

Keywords: Technical Vocational Education and Training (TVET); FDI's; LDC's; NGO's.

Cite This Article: Azmat Ullah, and Farnaz Parveen. (2018). "SIGNIFICANCE ROLE OF TVET FOR DEVELOPING COUNTRY: STUDY ON BANGLADESH PERSPECTIVE." International Journal of Research - Granthaalayah, 6(7), 300-305.

\section{Introduction}

Bangladesh's 6th Five Year Plan (FY2011-FY2015) is entitled “Accelerating Growth and Reducing Poverty". Bangladesh wants to achieve Middle Income Status by 2021 and in order to achieve this goal must increase the proportion of higher value added manufacturing from 18 to 25 $\%$ of the gross domestic product (GDP). This will require a number of factors but three primary ones are: increased investment, improve labour productivity through increased skills, and increase trade. The Plan stresses employment as a major instrument for poverty reduction. It acknowledges the important contribution that the private sector as well as non-government organizations can have in strengthening government provision of TVET and the role TVET can have in productivity improvement as well as in meeting the needs of disadvantaged groups who need to acquire skills for employment. It further recognizes the value that skills development for workers going abroad has on their employment opportunities as well as on the size of remittances they send back.

It is observed that lately that the infrastructure development, in less developed countries (LDC's) especially in Africa and Asia, is not any longer the prime problem for development. These LDCs have already made significant improvement in addressing energy, infrastructure and 
communication issues. Increased inflow of Foreign Direct Investment (FDI) from developed economies of the world like USA, UK, Japan, France, Germany has played a critical role in such improvements.

\subsection{Rationale of the Study}

Bangladesh is a densely populated country with approximately 160 million people and of these, labor force of approximately 60 million.

Technical and vocational education and training (TVET) is responsible for the development of human resource of this country. "In the National Strategy for Accelerated Poverty Reduction (2005), the emphasis is given to the enhancement of workers' skills resulting in the "Improvement of the percentage of vocational and technical graduates obtaining employment both in the domestic and international markets".

Bangladesh has shown milestone d achievements in its economic development. For past few years it has maintained an average of $6 \%$ growth of the GDP per year and the rate of employment has risen by $4.5 \%$ every year.

\subsection{Objectives of the Study}

This study focuses on the following objectives:

1) Understanding the concept of TVET in Bangladesh context.

2) Stating the TVET education in Bangladesh

\section{Literature Review}

TVET is defined as a comprehensive term referring to those aspects of the educational process involving, in addition to general education: - the study of technologies and related sciences.

More than nineteen Ministries operate technical training institutes including Ministry of Labour and Employment, Ministry of Education (Directorate of Technical Education), Ministry of Agriculture, offering courses at different levels ranging from high school to Polytechnic.

Many institutions also offer a variety of short courses ranging from just a few weeks up to six months. One of the most popular is the basic trade course of 360 hours over six months with some $20,000+$ students registered. Whereas government TVET institutions number about 200, private sector institutions number more than 3000. The Bureau for Manpower Employment (BMET) operates 38 technical training centers which have a focus on training workers for overseas.

Since the 1950s there have been at least three main schools of thought on the definitions and approaches towards development. The first school is that of the economists. Economists (e.g. Bernstein, Shultz, Psacharapolous) view development primarily in terms of a nation's relative prosperity. A nation's development is assessed by measuring any increase in its gross national product (GNP) (Thomas and Potter, 1992). Development is achieved through investing in human capital and "raising the productivity capacities of societies" (Thomas and Potter, 1992). 
The second school of thought is that of the sociologists (e.g. McClelland, Weber, Inkeles, Smith). They propose that modernizing a country leads to economic development and a modern society. With modernization as the main goal, the emphasis is placed on education, technology and industrialization as the agents of transformation.

Underdeveloped countries can, they say, be transformed into modern countries with similar economies, societies and politics as those in the prosperous west (Thomas and Potter, 1992; Little, 1999). In the 1960s and 1970s, another group of theorists (e.g. Seers, Sen, Edwards) began to consider development from a human needs perspective. The emphasis here was not so heavily focused on economic growth as the primary indicator of development, but more on assessing the needs of individuals: their freedom, equity, participation and empowerment to fulfil their potential capabilities (Thomas and Potter, 1992).

It is important to note that this comparison does not consider the quality of education provided in the countries included. Furthermore, GDP has been calculated to include foreign aid received by underdeveloped countries from developed countries. In some countries, a lower income (GNP) produces a better quality of life, due to the correct balance between income and the purchasing power controlling the value of basic goods. Conversely, corruption is an aspect of social decadence that will hinder any level of National Development-ND (Alam,2009; Woodhall, 1997).

\subsection{The Positive Ways of Application Technical Vocational Education and Training (TVET)'}

Jeong (1999) claims that before joining the labor force, workers need to be trained to be more productive and to perform their task properly. Atcharena and Caillods (1999) say that workers need the training before joining the labor force and also need in service training to maintain up-todate skills. But Bangladesh has taken the decision to build more traditional educational institutions rather than TVET institution, which has resulted in producing graduates rather than skilled person power.

TVET is inherently multidisciplinary hi nature and depends to a significant extent on specialists from the relevant disciplines in the country, as well as those in developed countries where development has been progressed through multidisciplinary activities (Watts, 1985). So the multidisciplinary nature of TVET may help the students to reach the labor market and further education with a solid foundation. Under such circumstances, there are many unemployed young people in Bangladesh. Such people are engaged socially.

\section{Methodology}

This paper is based upon secondary data collected from various published sources, newspapers, journals and books. This paper has also explained the sources containing information relating to TVET development in Bangladesh over the recent period. This paper is limited in its focus and reaches of recent data as it is highly relied on available information in public source. 


\section{Education System in Bangladesh}

Education in Bangladesh has three major stages - primary, secondary and higher educations. Primary education is a 5-year cycle while secondary education is a 7-year one with three substages: 3 years of junior secondary, 2 years of secondary and 2 years of higher secondary. The entry age for primary is 6 years. The junior, secondary and higher stages are designed for age groups as 11-13, 14-15 and 16-17 years respectively. Higher secondary is followed by graduate level education in general, technical, engineering, agriculture, business studies, and medical streams requiring 5-6 years to obtain a Master degree.

In the general education stream, higher secondary is followed by college/university education through the Pass Course (3 years)/Honors (Undergraduate) Course (4 years). The Master Degree is of one year duration for the holders of Bachelor Degree (Honors) and two year duration for the holders of Bachelor Degree (Pass). Higher education in the technical area also starts after higher secondary level. Engineering, agriculture, business, medical and information \& communication technology are the major technical and technological education areas.

Primary level education is provided under two major institutional arrangements, general and madrasha, while secondary education has three major streams: general, technical-vocational and madrasha. Higher education, likewise, has 3 streams: general (inclusive of pure and applied science, arts, business and social science), madrasha and technology education. Technology education in its turn includes agriculture, engineering, medical, textile, leather technology and ICT. Madrashas (Arabic-oriented educational institution), functioning parallel to the three major stages, have similar core courses as in the general stream (primary, secondary and post-secondary) but have additional emphasis on religious studies.

Education System in Bangladesh is being managed and administered by two Ministries, Ministry of Education (MoE) and Ministry of Primary and Mass Education Division in association with the attached Departments and Directorates as well as a number of both government and autonomous bodies.

\section{Background of TVET Education In BD}

In 1979, National Council for Skill Development and Training (NCSDT) was established through government resolution authorized by the President. High level representatives from 22 different organizations including 2 members of Parliament, concerned Ministry, Labor Union and Chambers of Commerce and Industries are the members of NCSDT. In 1987, government has changed its name and addressed it by new name, that is, Directorate of Technical Education (DTE).

DTE sets and controls the overall policy framework of the entire vocational education and training system. It makes a relationship between government and" TVET-program. DTE, responsible for formulation of government policies on TVET, implements government programs and makes collaborations with public-private organizations with TVET. The main objectives of DTE are:

1) Assessing the need for skilled and semi-skilled manpower at all levels

2) Preparing policy guidelines for consolidating, improving and expanding VET

3) Preparing project proposals 
4) Continuous monitoring and evaluating of the development and implementation of projects

5) Preparing the annual budget and allocating funds

\subsection{Status of TVET Education in Bangladesh Context}

TVET consists of three levels in Bangladesh. The first level, for two years, is focusing on basic or manual skills. The prospective students have to join after completion of standard VIII and continue two years for attaining Secondary School Certificate (SSC) (Voc). After SSC (Voc), students may continue more to get Higher Secondary Certificate that is, HSC (Voc), but it requires additional two years of secondary schooling after grade 10. At the post-secondary level, there are four year diploma level courses, which are offered through polytechnic institutions.

Table 1: Status of TVET Education Statistics-2014 (Source BANBEIS)

\begin{tabular}{|l|l|l|l|l|l|l|l|l|l|}
\hline Type & Management & \multicolumn{3}{|l|}{$\begin{array}{l}\text { Number of } \\
\text { Institutions }\end{array}$} & \multicolumn{3}{|l|}{ Number of Teachers } & \multicolumn{3}{l|}{ Number of Students } \\
\cline { 3 - 11 } & & Total & Female & Total & Female & \% Female & Total & Girls & \% Girls \\
\hline $\begin{array}{l}\text { Polytechnic } \\
\text { Institutes }\end{array}$ & Public & 46 & n/a & 1486 & 174 & 11.71 & 90512 & 11007 & 12.16 \\
\cline { 2 - 11 } & Private & 240 & n/a & 3179 & 587 & 18.46 & 79557 & 8256 & 10.38 \\
\cline { 2 - 10 } & Total & 286 & n/a & 4665 & 761 & 16.31 & 170069 & 19263 & 11.33 \\
\hline $\begin{array}{l}\text { Technical } \\
\text { Schools } \\
\text { Colleges }\end{array}$ & Public & 64 & n/a & 1140 & 125 & 10.96 & 36418 & 4908 & 13.48 \\
\cline { 3 - 10 } & Private & 106 & n/a & 1166 & 295 & 25.30 & 28508 & 8844 & 31.02 \\
\hline
\end{tabular}

\subsection{Strategies for Upgrading TVET in Bangladesh}

Many employers are unaware of the skills and competence that are developed by the technical and vocational educational programs in the institutes. Employers should be made aware of the products of the technical education, and they should be encouraged to recruit the technical and vocational graduates, which may reduce their on-the-job training expenses and improved efficiency of their operations.

Initiatives should be taken to make the technical vocational education and training (TVET) system more market-oriented. As the new industries are emerging and new operations are emerging with the advent of the new technologies, VET should reorganize their curriculum and training methods to equip their graduates with improved and modern skills that are sought by the employers.

Along with the technical and trade-specific skills, TVET graduates should be equipped with a substantial amount of general managerial and entrepreneurial skills by the institutes. Such combination will make the VET attractive for the participants, as it will increase the professional horizons of the VET graduates. It will facilitate the VET graduates to realize their self-actualization as managers and entrepreneurs, which will certainly inspire the change of social taboos toward TVET. 


\section{Conclusion}

Bangladesh is a country with endless potentialities for development and growth. The Millennium Development Goal (MDG) successfully has made the country a self sustainable one. A huge manpower still waits to be explored. Manpower if could be vocationally trained could double our foreign remittances and assist in increasing our foreign currency reserves.

Now in 2016, Kingdom of Saudi Arabia lifting its bar and giving access to almost five hundred thousand of labors have certainly enhanced the need of vocational institutes as most of our manpower export is of unskilled and semi skilled and skilled labor force thus TVET application is expected to play a vital role in Bangladesh's development.

\section{References}

[1] Atcharena, D., \& Caillods, F. (1999). Technical education: A dead end or adapting to change? Prospect, 29(1), 67-87.

[2] Bangladesh Bank (2004). Retrieved 13 February 2016 from http://www.bangladesh-bank.org/pub.

[3] Bangladesh Bureau of Educational Information and Statistics (BANBEIS). (2007). Ministry of Education, Bangladesh.

[4] Bangladesh Computer Council. (2001). Retrieved 13 February 2016 from http://www.bccbd.org.

[5] Bangladesh Garment Manufacturers and Exporters Association (BGMEA). (2001). Statistics of export income and role of garments industries. Dhaka, Bangladesh.

[6] Bangladesh Technical Education Board (BTEB). (1994). A study of job market for VTI graduates. Dhaka, Bangladesh.

[7] Bennell, P. (1996). GENERAL VERSUS VOCATIONAL SECONDARY EDUCATION IN DEVELOPING COUNTRY: A REVIEW OF RATES OF RETURN EVIDENCE. The Journal of Development Studies, 33(2), 230-247.

[8] Jeong, K. (1999). STRUCTURAL ADJUSTMENT AND VOCATIONAL EDUCATION IN THE REPUBLIC OF KOREA: THE STRUGGLE BETWEEN MARKETS AND INTUITIONAL SYSTEM. Prospects, 29 (1), 89-104.

[9] Kothari, C.R. (2004). Research Methodology - Methods and Techniques - New age International Publishers Limited, pp. 122-128.

[10] Kyempong, A.K. (2002). Vocationalization on Secondary Education in Ghana.

[11] Little, A.W., \& Leach F.E. (1999). DEVELOPMENT AND EDUCATION, CULTURE AND ECONOMICS ANALYSIS: EDUCATION CULTURES AND ECONOMICS - DILEMMAS FOR DEVELOPMENT. Brighton, UK: Falmer.

[12] Malhotra, N.K. (2013). Marketing Research (6thed.) Boston, MA: Pearson Education, pp. 407408.

[13] Thomas, A., Potter, D.. \& Allen, T. (1992). DEVELOPMENT, CAPITALISM AND THE NATION STATE: POVERTY AND DEVELOPMENT IN THE 1990S. Milton, Keynes: Open University Press.

[14] Tilak, J. B. (2003). Vocational Education and Training in Asia. International Handbook of Educational Research in the Asia-Pacific Region, Springer: 673-686.

[15] Watts, A.G. (1985). EDUCATION AND EMPLOYMENT. LONDON: The Open University.

[16] Zikmund, W.G, Babin, B. J., Carr, J. C. \& Griffin, M. (2014). Business Research Methods (8th ed.). South-Western Cengage Learning, pp. 463-488.

*Corresponding author.

E-mail address: azmat.pstu@ yahoo.com 